\title{
The Cunaxid Mite Neocunaxoides andrei (Baker \& Hoffmann) as a Biological Control Agent of the Root-Knot Nematode Meloidogyne javanica Chitwood
}

\author{
Salwa M. E. Shoala* and Gamal A. El Kady ${ }^{* *}$ \\ *Plant Protection Research Institute, Dokki, Giza. \\ ${ }^{* *}$ Faculty of Agriculture, Suez Canal University, Ismailia
}

\begin{abstract}
Feeding capacity of the cunaxid mite Neocunaxoides andrei (Baker \& Hoffmann) and its feeding capability on the rootknot nematode Meloilogyne javanica Chitwood, under laboratory or semi field conditions were studied. Results showed that, a female of $N$. andrei consumed an average of 177.2 second juvenile stage (j2s) of $M$. javanica within five days under the laboratory conditions of $26 \pm 1{ }^{\circ} \mathrm{C}$ and $70 \pm 5 \%$ R.H. Data also indicated that, the presence of 20,40 and 60 newly emerged $N$. andrei females together with $500 \mathrm{j} 2 \mathrm{~s}$ M. javanica in pots planted with tomato seedlings 15 days old caused a reduction of about $59 \%, 74 \%$ and $86 \%$ of M. javanica reached adult females after 30 days.
\end{abstract}

Key Words: Cunaxid mite, Neocunaxoides andrei, Root-knot nematode, Meloilogyne javanica, Biological control, Feeding capacity.

\section{INTRODUCTION}

The root-knot nematodes, Meloidogyne species are major yield- limiting pathogens in many crop production areas allover the world. Genus Meloilogyne is considered of a major economic importance (Karssen and Hoenselaar, 1998). In Egypt, the root-knot nematodes are recognized as major agricultural pests of a wide range of crops including, vegetables, fruits and ornamental crops (Oteifa, 1964; Oteifa and Tarjan, 1965). The Meloidgyne species as $M$. incognita Chitwood, $M$. javanica Chitwood and $M$. arenaria Chitwood are widely distributed in northern Egypt (El-Saedy et al., 1993 and Ibrahim et al., 1994). The geographical distribution of the root-knot nematode $M$. javanica is most abundant in sand soil and newly reclaimed land such as Nubaria, Tahrir province and Salhia districts followed by M. incognita (El-Gindi et al., 1980; Mahrous 1991 and El-Shawadfy, 1997).

Some predacious mites were recorded as a biological control agent of nematodes. Taha et al., (1988) studied the effect of feeding N. andrei on the nematode Panagrolimaus rigidus Schneider on its developmental time and fecundity under laboratory conditions of $30^{\circ} \mathrm{C}$ and $70 \%$ R.H.. Walter and Kaplan (1991) found that Coloscerius simplex (Ewing) colonized greenhouse pot cultures of the root- knot nematodes (Meloilogyne spp.) when it fed on vermiform nematode and other soil arthropods. They also studied feeding behavior of Cunaxid mites. Mostafa et al., (1997) reported that Lasioseius dentatus Fox could develop on egg masses of $M$. javanica under laboratory conditions.

El-Khateeb (1998) reared Coloscerius aegyptiacus Gomaa \& El-Khateeb on the free-living nematode, Rhabiditella miscicola, while Sholla (2000) reared Coloscerius buratus Den Heyer on the free-living nematode, $R$. miscicola at $26^{\circ} \mathrm{C}$ and $70 \%$ R.H.

El-Hady and El-Naggar (2001) studied the possibility of using both predacious laelapid mites Hyoaspis bregetovae (Shereef \& Afifi) and $H$. sardoa Berlese as biological control agents of the Root-Knot nematode on sunflower plants. On the other hand, Maareg et al., (2005) reported seven predacious mites species from sugar beet field. These mites were evaluated for their predacious activity on immature stages of $M$. incognita. The results revealed that all tested soil mites except Cunaxa sp. fed on immature stage of nematode.

However, the aim of the present work is to study the effect of the predatory mite Neocunaxoides andrei (Baker \& Hoffmann) as a biological control agent on the root-knot nematode $M$. javanica under laboratory and semi field conditions.

\section{MATERIALS AND METHODS}

\section{Rearing cells technique:}

Rearing cells made of a closed round transparent plastic containers measuring $5 \mathrm{~cm}$ in diameter and $2 \mathrm{~cm}$ height filled up to $0.5 \mathrm{~cm}$ with plaster of Paris and charcoal of $(9: 1 \mathrm{w} / \mathrm{w})$ and closed tightly. The rearing cells were maintained at incubator at $26 \pm 1{ }^{\circ}$ Cand $70 \pm 5 \%$ R.H.

\section{Preparation of pure culture of the predacious mite $N$. andrei: \\ Females of $N$. andrei collected from soil samples were transferred singly to rearing cells supplied daily with enough numbers of juvenile stages (j2s)}


root- Knot nematode $M$. javanica as a food source. The deposited eggs of the mite were left to develop and the resulted females were mounted for identification.

\section{Root- knot stock culture:}

The original inoculum of the root-knot nematode $M$. javanica was obtained from galled roots of tomato grown in the field of Faculty of Agriculture, Suez Canal University. Nematode egg masses were collected from nematode galls and introduced to tomato roots. Newly hatched juvenile stages were obtained by incubating egg masses on modified Baermann units.

\section{Semi-field condition:}

Tomato seeds were sown in small plastic pots (15-cm in diameter) containing $500 \mathrm{~g}$ steam sterilized sandy-peat soil $(1: 1 \mathrm{v} / \mathrm{v})$ under greenhouse condition about $31.5^{\circ} \mathrm{C}$ ranged from $30^{\circ} \mathrm{C}$ to $34^{\circ} \mathrm{C}$. After 15 days, the tomato seedlings were inoculated with $500 \mathrm{j} 2 \mathrm{~s}$ M. javanica/pot around the root. Adult 20, 40 and 60 newly emerged adult cunaxid females were added/pot as soon as the nematode inoculation was conducted. Another pot of tomato plant was inoculated with nematodes only as a control check. The reduction of nematode caused by mites was assessed after 30 days. Water was added carefully when needed. The plants were uprooted and the population of the female nematodes was determined in roots following the method used by Franklin (1949). The experiment was conducted using a complete randomized design with three replicates.

\section{Laboratory condition:}

For food consumption of $N$. andrei on the rootknot nematode $M$. javanica, about $100 \mathrm{j} 2 \mathrm{~s}$ were added daily during five days. The consumed j2s were removed and counted.

Statistical analysis: Data obtained were statistically analyzed by using Costat software programs, Twoway ANOVA for significant differences between means.

\section{RESULTS AND DISCUSSION}

Data given in table (1) indicated that the majority of nematode $\mathrm{j} 2 \mathrm{~s}$ penetrated the tomato roots within 5 days. Mean number of $\mathrm{j} 2 \mathrm{~s}$ consumed by $N$. andrei under laboratory condition ranged from $30.8 \pm 6.3$ to $35.8 \pm 4.16$ five days before the nematode injected the roots (Table 2).

Results given in table (3) show that the average number of female nematode decreased significantly as the number of the cunaxid mite increased. The caused reduction reached $86.2 \%, 74 \%$ and $59.3 \%$, when the cunaxid mites per pot were 60,40 and 20 females, respectively. The average number of nematode females was 122.6 individuals per control pots.

The average number of galls decreased significantly as the number of the cunaxid mite increased. The caused reduction reached $84.9 \% \%$, $70.2 \%$ and $57.4 \%$, when the cunaxid mites per pot were 60,40 and 20 females, respectively. The average number of galls was 124.5 individuals per control pots.

The average number of nematodes per $500 \mathrm{~g}$ soil decreased significantly as the number of the cunaxid mite increased. The reduction reached $81.1 \%$, $80.0 \%$ and $76.9 \%$ when the cunaxid mites per pot were 60,40 and 20 females, respectively. The average number of nematodes per $500 \mathrm{~g}$ soil was $2166.5 \pm 53.2$ individuals per control pots.

The present results agree with that recorded by Taha et al., (1988) who studied the effect of different prey on the development and fecundity of the predacious mite $N$. andrei and found that when mites fed on Panagroliaimus rigidus (Schneider) nematode, the immatures developed faster and adult females laid a greater numbers of eggs than those fed on acarid mites.

Also obtained data agree with that found by Mostafa, et al. (1997) who studied the biological control of $M$. javanica infecting tomato, using the laelapid predaceous mite Lasiosieus dentatus (Fox). Aldicarb treatment and $L$. dentatus applied either at the same time or 40 days after, showed remarkable improvement on tomato growth.

On the other hand, Amin et al. (1999) found that the highest reduction in total number of the nematodes occurred when the mite L. athiasae was applied four days before nematode inoculation compared with adding mites one day and two days before nematode inoculation.

Also El-Hady and El-Naggar (2001) studied the possibility of the control of egg masses of the rootknot nematode $M$. incognita on sunflower plants by certain predaceous mites. Mites were added to the soil one to three days before inoculation of nematode on roots of sunflower plants. This resulted in reduction of the total number of nematodes. Highest reduction in total nematodes occurred when the mites were applied 3 days before nematode 
Table (1): Daily average number of a live Meloilogyne javanica juvenile injected in $500 \mathrm{gm}$ soil within 5 days under $26 \pm 1^{\circ} \mathrm{C}$ and $70 \%$ R.H.

\begin{tabular}{ccccccc}
\hline $\begin{array}{c}\text { Average No. } \\
\text { Juvenile }\end{array}$ & $1^{\text {st }}$ & $2^{\text {nd }}$ & $3^{\text {rd }}$ & $4^{\text {th }}$ & $5^{\text {th }}$ & $\begin{array}{c}\text { Mean of } \\
\text { total }\end{array}$ \\
\hline Min. No. & 420 & 290 & 180 & 40 & 5 \\
\hline Max. No. & 470 & 420 & 230 & 90 & 20 \\
\hline
\end{tabular}

Means \pm S.D $\quad 448 \pm 19.2 \quad 366 \pm 50.29202 \pm 19.2 \quad 68 \pm 19.2 \quad 11 \pm 5.47 \quad 219 \pm 17.28$
Table (2): Daily average number of consumed Meloilogyne javanica by Neocunaxoides andrei under laboratory condition $\left(26 \pm 11^{\circ} \mathrm{C}\right.$ and $70 \%$ R.H) with in 5 days.

\begin{tabular}{cccc}
\hline \multicolumn{4}{c}{ No. consumed juvenile M. javanica } \\
\hline Days & Minimum & Maximum & Average \pm S.D \\
\hline $1^{\text {st }}$ & 22 & 40 & $30.8 \pm 6.33$ \\
\hline $2^{\text {nd }}$ & 30 & 45 & $37.8 \pm 5.03$ \\
\hline $3^{\text {rd }}$ & 24 & 42 & $33.8 \pm 7.14$ \\
\hline $4^{\text {th }}$ & 36 & 48 & $40.5 \pm 4.41$ \\
\hline $5^{\text {th }}$ & 29 & 40 & $35.8 \pm 4.16$ \\
\hline Mean & & & $177.2 \pm 7.8$ \\
\hline
\end{tabular}

Table (3): Number of the root-knot nematode Meloilogyne javanica affected by different rates of the cunaxid mite Neocunaxoides andrei.

\begin{tabular}{|c|c|c|c|c|}
\hline \multirow{2}{*}{ Parameter } & \multicolumn{3}{|c|}{ No. cunaxid mites/pot } & \multirow{2}{*}{$\begin{array}{c}\text { Control (free of } \\
\text { mites) }\end{array}$} \\
\hline & 20 mites & 40 mites & 60 mites & \\
\hline Avg. No. nematode females & $50 \pm 0.8 \mathrm{~b}$ & $32 \pm 0.8 \mathrm{c}$ & $17 \pm 0.5 \mathrm{~d}$ & $122.6 \pm 50.1 \mathrm{a}$ \\
\hline Avg. No. of nematode galls & $53 \pm 6 b$ & $37.3 \pm 10.2 \mathrm{c}$ & $18.7 \pm 6.7 \mathrm{~d}$ & $124 . \mathrm{s} \pm 12.4 \mathrm{a}$ \\
\hline Avg. No .of nematode female/galls & $3 \pm 1$ & $2 \pm 1$ & $2 \pm 1$ & $4 \pm 1$ \\
\hline Avg. No.Nematodes/500gm soil & $500 \pm 20 \mathrm{~b}$ & $433 . \pm 11.5 \mathrm{c}$ & $408.5 \pm 55.7 \mathrm{c}$ & $2166.5 \pm 53.2 \mathrm{a}$ \\
\hline
\end{tabular}

Means followed by the same letter do not differ significantly ( $\mathrm{p} \leq 0.05)$.

inoculation.

Maareg et al., (2005) recorded seven predacious mites Proprioseiopsis messer (Wainstein), Cheyletus malaccensis (Oudemans), Cunaxa sp., Glycyphagus domesticus (De Geer), Macrochelus monchasolska (B\&K), Platyeseus major (Halbert) and Uropoda misella (Berlese) from sugar beet field. These mites were evaluated for their predacious activity on immature stages of $M$. incognita. The results revealed that the afore-mentioned soil mites except Cunaxa sp. fed on immature stages of nematode. On the other hand, Sholla, 2007 reported that numbers of egg masses of $M$. javanica were reduced by adding $N$. andrei to soil planted with cowpea and egg plant.

As a result, it could be concluded that the cunaxid mite $N$. andrei is considered an active biological control agent of the root-knot nematode M. javanica.

\section{REFERENCES}

Amin, A.W.; Mowafe, M.H. and Ali, Fatma S. 1999. Effect of predaceous mesostigmatid mites in the control of Meloidogyne javanica root-knot nematode on kidney bean. Pakistan J. of Nematology, 17 (1): 91-96.
El-Khateeb, H. M. 1998. Life tables of some predacious mites and their importance in biological control. Ph.D. Thesis, Fac. Agric. Cairo Univ.: $107-109$.

El-Saedy, M. A.; Hassan, M. W. A. and Sourour, M. M. 1993. Occurrence of plant parasitic nematodes and their effects on the nutrition of six fruit crops grown in Nubaria region. J. Agric. Sci., Mansoura Univ., 18: 530-537.

El-Shawadfy, M. M. 1997. Geographical distribution of root-knot nematodes and their threats to agriculture in Egypt. The $1^{\text {st }}$ Intr. Afro-Asian, Nematology Workshop, 39-44.

El-Gindi, D. M.; Salem, A. A. and Hashem, M. H. 1980. Structure of plant-parasitic nematode community in weedy soils in Sharquia Governorate effect of soil types. Zagazig J. Agric. Res., 7(1):371-381.

El-Hady, Mona. M. and El-Naggar, H. I. 2001. Possibility of the control of the root-knot nematode Meloidogyne incognita on sunflower plants by certain predaceous mites. J. Agric Sci., Mansoura Univ., 26(4): 2391-2395.

Franklin, M. T. 1949. A cotton blue lavtophenol technique for mounting plant parasitic nematodes. J. Helminthol, 23: 175-178.

Ibrahim, I. K. A.; El-Saedy, M. A. and El-Sherbiny, A. A. 1994. Survey study of phytoparasitic nematodes associated with some grasses, weeds 
and plants in northern Egypt. J. Agric. Sci., Mansoura Univ., 19: 937-982.

Karssen, G. and Hoenselaar, T. Van 1998. Revision of the genus Meloidogyne Goldi, 1992 (Nematoda: Heleroderidae) in Europe. Nematologica, 44: 713-788.

Maareg, M. F.; Gohar, I. M. A. and Rady, G. H. 2005. Predatory behavior of some soil mites towards root-knot nematode, Meloidogyne incognita infecting sugarbeet crop. Egypt. J. Agric Res., 83 (2): 527-536.

Mahrous, M.E. 1991. Phytonematodes associated with olive (Olea europeani) in newly reclaimed sandy soil with special refernce to root-knot nematodes (Meloidogyne spp.) Zagazig, J. Agric Res., 18(1): 187-192.

Mostafa, F. A.; Fouly, A. H. and El-Sherif, A. G. 1997. Biological control of Meloidogyne javanica infecting tomato by the predaceous mite Lasiosieus dentatus. Egypt. J. of Agronematology, 1(1): 113-120.

Oteifa, B. A. 1964: A taxonomic guide to the common genera of soil plant nematodes with a supplement on current known economic parasitic species of U.A.R. Contribution of the National
Research Center, pp. 27.

Oteifa, B. A. and Tarjan, A. C. (1965). Potentially important plant-parasitic nematodes present in established orchards of newly reclaimed sand areas of the U.A.R. Plant Dis Reptr., 49:596-597.

Sholla, Salwa, M. E. 2000. Taxonomical and biological studies on some predacious Actinedid mites M. Sc.Thesis, Fac., Agric. Ain Shams Univ.

Sholla, Salwa, M. E. 2007. Studies on some predacous and parasitic mites belonging to suborder Actinedida Ph.D. Thesis, Fac., Agric. Ain Shams Univ., pp. 77.

Taha, H. A.; El-Naggar, M. E. E., Abou-El-Naga, M. M. and Soliman, S. M. 1988. Effect of different prey species on the development and fecundity of the predacious mite, Neocunaxoides andrei (Baker and Hoff.) (Acari: Cunaxidae). Agric., Res., Revi., 66(1): 129-135.

Walter, D. E. and Kaplan, D. T. 1991. Observations on Coloscerius simplex (Acarina : Prostigmata), a predatory mite that colonizes greenhouse cultures of root- knot nematode (Meloilogyne spp.) and a review of feeding behavior in the Cunaxidae., Expr. Appl. Acarol., 12 (1-2): 47-59. 